\title{
Pregão eletrônico: um estudo das causas de cancelamento de itens no âmbito de uma universidade federal
}

\author{
Meryellem Yokoyama Neves \\ Universidade Federal de Santa Catarina (UFSC), Florianópolis, SC, Brasil \\ Rafael Pereira Ocampo Moré \\ Universidade Federal de Santa Catarina (UFSC), Florianópolis, SC, Brasil
}

\section{Resumo}

As instituições federais de ensino superior (Ifes), constituídas nas formas de fundações ou autarquias, por fazerem parte da administração pública, estão obrigadas a seguir as regras da licitação. Desse modo, a Universidade Federal de Santa Catarina (UFSC), por ser classificada como uma autarquia federal e estar sujeita às normas especificadas na Constituição Federal, deve adotar a licitação como meio para efetivação de suas compras. Esta pesquisa propõe analisar os cancelamentos de itens de material de consumo em pregões eletrônicos realizados no âmbito da Universidade Federal de Santa Catarina, no período de 2014 a 2018. A pesquisa, quanto aos fins, caracteriza-se como aplicada e descritiva. Quanto aos meios, foram utilizadas as pesquisas de campo, documental e bibliográfica. Dessa forma, considerando as informações identificadas a partir do cumprimento do objetivo, observa-se que a fase interna é de extrema importância para o sucesso da licitação, pois os principais motivos de cancelamento de itens, identificados neste estudo, estão relacionados diretamente à especificação do objeto e pesquisa de preços, os quais possuem relação direta com a fase preparatória do certame. Ações de aprimoramento para os processos de compras e licitações foram propostas; entre elas destaca-se a necessidade de maior conscientização e capacitação por parte dos servidores requerentes quanto às suas atribuições na fase interna do certame.

Palavras-chave: compras e licitações, pregão eletrônico, administração universitária 


\section{Pregón electrónico: un estudio de las causas del cancelación de artículos en una universidad federal}

Las instituciones federales de enseñanza superior (IFES), constituidas en las formas de fundaciones o autarquías, por formar parte de la administración pública, están obligadas a seguir las reglas de la licitación. De este modo, la Universidad Federal de Santa Catarina (UFSC), por ser clasificada como una autarquía federal y estar sujeta a las normas especificadas en la Constitución Federal, debe adoptar la licitación como medio para la efectivización de sus compras. Esta investigación propone analizar las cancelaciones de artículos de material de consumo en pregones electrónicos realizados en el ámbito de la Universidad Federal de Santa Catarina, en el período de 2014 a 2018. La investigación, en cuanto a los fines, se caracteriza como aplicada y descriptiva, se utilizaron las investigaciones de campo, documental y bibliográfica. De esta forma, considerando las informaciones identificadas a partir del cumplimiento del objetivo, se observa que la fase interna es de extrema importancia para el éxito de la licitación, pues los principales motivos de cancelación de ítems, identificados en este estudio, están relacionados directamente a la especificación del producto, objeto e investigación de precios, los cuales poseen relación directa con la fase preparatoria del certamen. Las acciones de mejora para los procesos de compras y licitaciones fueron propuestas, entre ellas se destaca la necesidad de mayor concientización y capacitación por parte de los servidores solicitantes en cuanto a sus atribuciones en la fase interna del certamen.

Palabras clave: compras y licitaciones, pregón electrónico, administración universitaria

\section{Electronic auctions: a study of reasons about cancellation items in a federal university}

The federal institutions of higher education (IFES), constituted in the forms of foundations or autarchies, for being part of the public administration, are obliged to follow the rules of the bidding. Thus, the Federal University of Santa Catarina (UFSC), because it is classified as a federal authority and subject to the norms specified in the Federal Constitution, must adopt the bidding as a means of effecting its purchases. This research proposes to analyze the cancellations of items of consumer material in electronic previews carried out within the scope of the Federal University of Santa Catarina, from 2014 to 2018. The research, in terms of purposes, is characterized as applied and descriptive, and for the field, documentary and bibliographical research were used. In this way, considering the information identified from the accomplishment of the objective, it is observed that the internal phase is of extreme importance for the success of the bid, since the main reasons for cancellation of items, identified in this study, are directly related to the specification of the object and price survey, which are directly related to the preparatory phase of the event. Improvement actions for the procurement and bidding processes were proposed, among them the need for greater awareness and qualification by the requesting employees regarding their assignments in the internal phase of the event.

Keywords: purchases and bids, electronic trading, university administration 


\section{Introdução}

A responsabilidade dos agentes públicos na adequada aplicação do orçamento das instituições públicas tem aumentado, já que a fiscalização dos atos administrativos relacionados à utilização dos recursos públicos também tem se tornado mais ampla e eficaz. Tal fato pode ser comprovado pelo número de leis e decretos que foram surgindo sobre o tema, desde a Constituição Federal de 1988, visando incrementar e modernizar a Lei no 8.666 de 1993, conhecida como Lei de Licitações, vigente há 26 anos.

Parte-se do pressuposto de que a administração pública só pode fazer o que a lei estabelece. Nesse sentido, a licitação é regulada pela Lei no 8.666/93, que apresenta as normas que norteiam o cumprimento do artigo 37, inciso XXI, da Constituição Federal; pela Lei no 10.520/02, que institui a modalidade de licitação denominada pregão, que visa à aquisição de bens e serviços comuns; e regulada também pela Lei no 12.462/11, que institui o Regime Diferenciado de Contratações Públicas. Além disso, somam-se os decretos, instruções e orientações que normatizam a aplicação das leis.

$\mathrm{Na}$ condução dos processos licitatórios, para que seja assegurada a igualdade de condições a todos que desejam contratar com a administração pública, é necessário o cumprimento de princípios da legalidade, impessoalidade, moralidade, publicidade e eficiência, conforme previstos no artigo 37 da Constituição Federal, e ainda os princípios previstos no artigo 3ㅇ da Lei no 8.666/93, tais como a isonomia, probidade administrativa, julgamento objetivo e vinculação ao instrumento convocatório.

Contudo, registra-se a problemática referente à instrução dos processos de compras e licitações, em toda a administração pública, em razão da necessidade de seguir os preceitos legais e ser alvo de atenção dos servidores que participam desses processos, visando evitar futuros retrabalhos e desperdício de recursos públicos e humanos.

Para tanto, é necessário que os agentes públicos tenham conhecimento acerca das normas que regem as licitações - e muitas vezes não o possuem - para que as compras públicas sejam feitas de forma correta e eficiente, atendendo a todos os seus princípios norteadores, e, nesse sentido, é apresentada a pergunta de pesquisa: de que forma as 


\section{características dos processos licitatórios motivam o cancelamento de itens de material de consumo em pregões eletrônicos realizados no âmbito da UFSC?}

As instituições federais de ensino superior (Ifes), constituídas na forma de fundações ou autarquias, por fazerem parte da administração pública, mesmo que em sua forma indireta, estão obrigadas a seguir as regras da licitação.

A partir da análise dos cancelamentos de itens de material de consumo em pregões eletrônicos realizados no âmbito da UFSC, no período de 2014 a 2018, pretende-se contribuir com informações gerenciais dos motivos reais referentes aos cancelamentos no tocante ao campo empírico estudado, assim como sugerir encaminhamentos que possam evitar tais problemas em órgãos equivalentes da administração pública.

Porfim, apresenta-se a estrutura do trabalho da seguinte forma: Introdução; Referencial teórico, com temas relacionados à administração pública, pregão eletrônico, gestão de processos e gestão do conhecimento; Metodologia; Resultados; e Considerações finais.

\section{Fundamentação teórica}

Diferente do que ocorre em empresas privadas, que possuem liberdade para adquirir um bem e podem fazer tudo que a lei não proíbe, a administração pública, direta e indireta, só poderá fazer o que a lei permite. Sendo assim, conforme previsto no artigo 37, inciso XXI da Constituição Federal de 1988, a administração pública só poderá adquirir um bem ou contratar um serviço mediante processo licitatório. Nesse sentido, Coelho (2004) afirma que, ao contrário do que ocorre com os particulares, a administração pública não tem liberdade de escolha para contratar. Assim, deverá proceder à licitação na qual se assegure a igualdade entre os participantes, salvo as exceções previstas na legislação.

A legislação aplicada às licitações e contratos realizados pela administração pública compreende a Lei $n$ o 8.666, de 21 de junho de 1993, que regulamenta o artigo 37, inciso XXI, da Constituição Federal de 1988.

Por sua vez, Niebuhr (2012) destaca que a Lei $n$ ㅇ 8.666/93 compreende diversos 
artigos, a maior parte deles fragmentada em vários parágrafos, inciso e alíneas, cujo teor constitui um emaranhado de normas que praticamente exaurem a matéria. Além de servir como norteadora para as compras públicas, atendendo aos preceitos constitucionais, a Lei no 8.666/93 foi criada com o intuito de barrar e extinguir atos de corrupção e fraudes nas licitações e contratações do setor público.

Nesse sentido, a licitação deve ser o principal meio para aquisição de bens e serviços no setor público. Assim, para adquirir um bem ou contratar um serviço pela administração pública, os agentes públicos devem observar as normas dispostas em lei, visando identificar a proposta mais vantajosa em termos econômicos e de qualidade. Di Pietro (2013) define licitação como sendo o procedimento administrativo pelo qual um ente público abre a possibilidade, aos interessados, de formularem propostas, dentre as quais selecionará e aceitará a mais conveniente para a celebração de contrato.

É importante destacar ainda que, nas palavras de Olivo (2012, p. 24) “[...] é preciso entender que o procedimento licitatório tem dois objetivos bem claros: garantir a observância do princípio constitucional da isonomia; e selecionar a proposta mais vantajosa para a Administração". Por melhor proposta pode se entender não somente aquela que oferecer o menor preço, mas a que guardar consonância com os requisitos impostos pela administração como necessários à sua elaboração. Sendo assim, de nada adianta uma proposta que apresente valor reduzido se, na sua elaboração, não foram obedecidos os critérios previstos expressamente no instrumento convocatório.

Nota-se, pelo número de leis e decretos sobre o tema, uma busca constante pela atualização das normas que regem as licitações. A instituição da modalidade pregão, o Regime Diferenciado de Contratação (RDC), as compras sustentáveis e a atualização dos valores para licitações e contratos são alguns exemplos de aperfeiçoamento e otimização de procedimentos. Júnior (2009) comenta que, desde o nascimento da Lei no 8.666/93, ela é alvo de fluxo ininterrupto de modificações e aperfeiçoamentos, sem contar a grande quantidade de instruções e orientações normativas. 


\subsection{Pregão eletrônico}

O pregão é uma modalidade de licitação que busca incrementar a competitividade e agilizar as contratações públicas (BITTENCOURT, 2010). Apresenta características como a inversão de fases, quando comparado com as demais modalidades, desenvolvendo-se por procedimento mais ágil, célere e racional. Um dos grandes pontos positivos do pregão, de acordo com Santana (2009), foi inverter a fase de habilitação em relação à análise da verificação da proposta comercial. Diferentemente do que ocorre na licitação convencional, o preço é discutido em primeiro lugar, o que confere agilidade ao certame, pois a administração somente realiza a habilitação do licitante vencedor na oferta de lances (SANTANA, 2009).

A Lei do Pregão, ao contrário da Lei no 8.666/93, nunca foi alterada na sua essência, em 17 anos de existência. O motivo disso é, segundo Santana (2009), a simplicidade que reveste essa modalidade. O pregão pode ser executado de duas formas, presencial e eletrônica. Define-se o pregão como o gênero, e as modalidades presencial e eletrônica, como as espécies. Essas espécies, por certo, têm características comuns do gênero e próprias da espécie, permitindo sua distinção (GASPARINI, 2009, p. 32).

Em sua forma eletrônica, objeto de investigação neste estudo, o pregão é regulamentado pelo Decreto no 5.450 , de 31 de maio de 2005. Tem como objetivo aumentar a quantidade de participantes nos processos licitatórios, permitindo uma maior disputa entre os concorrentes. Olivo (2012) explica que a forma eletrônica consiste no tipo menor preço, visando à seleção da proposta mais vantajosa, através de propostas seguidas de lances, em que os atos da administração pública e dos interessados são feitos com utilização da internet. Gasparini (2009, p. 31) define o pregão eletrônico como "a espécie de pregão em que a disputa pelo fornecimento de bens ou prestação de serviços comuns à Administração Pública é feita à distância, em tempo real e em sessão pública, por meio de propostas de preços e lances visando melhorá-las, apresentados pela internet".

De acordo com o Manual do Pregão Eletrônico - Pregoeiro parte I, disponibilizado no portal Comprasnet:

Esta modalidade de licitação, destinada à aquisição de bens e serviços comuns, possui como importante característica a celeridade nos processos licitatórios, minimizando 
custos para a Administração Pública e vem se consolidando como a principal forma de contratação do Governo Federal (COMPRASNET, 2006, p. 5).

A obrigatoriedade da utilização desta modalidade na esfera federal está prevista no artigo 4을 do Decreto № 5.450/05, que determina que, para aquisição de bens e serviços comuns, deverá ser utilizado o pregão, preferencialmente em sua forma eletrônica. Apesar de ser uma modalidade obrigatória apenas na esfera federal, diversos estados e municípios também exerceram sua competência normativa e editaram normas complementares à lei federal. Para Justen Filho (2005), não será surpresa se, dentro de alguns anos, o pregão presencial se configurar como uma raridade. À medida que as diferentes unidades administrativas forem instituindo o pregão eletrônico, este passará a ser a alternativa dominante, produzindo a redução da relevância do pregão comum (presencial).

A instituição do pregão como modalidade licitatória foi uma inovação no sistema de compras da administração pública. Reduzindo o número de contratos precedidos de dispensa e inexigibilidade de licitação, minimizou o tempo dispensado com os certames em geral e proporcionou considerável diminuição de custos nas compras governamentais (GASPARINI, 2009). Justen Filho destaca ainda que:

Em termos essenciais, as vantagens são (a) o potencial incremento das vantagens econômicas em favor da Administração, (b) a ampliação do universo de licitantes e (c) a simplificação do procedimento licitatório. Outras vantagens poderiam ser apontadas, tal como a redução de custos no pregão eletrônico e maior rapidez na conclusão do certame (JUSTEN FILHO, 2013, p. 20).

De acordo com o artigo 3ㅇ da Lei $n$ o 10.520/02, os elementos da fase interna do pregão devem contemplar: i) abertura do processo e justificativa da autoridade; ii) definição do objeto; iii) orçamentação; iv) critérios de aceitação das propostas; v) requisitos de habilitação; vi) definição das sanções por inadimplemento; vii) termo de referência; viii) minuta do edital; ix) minuta do contrato; $x$ ) cumprimento da lei de responsabilidade fiscal; e xi) designação do pregoeiro e equipe de apoio.

Entre os elementos da fase preparatória do pregão eletrônico apresentados no artigo 9을 do Decreto $\mathrm{n}$ - 5.450/05, o termo de referência ganha destaque. De acordo com o Decreto no 3.555/00, o documento deverá conter aspectos capazes de propiciar a avaliação do custo pela administração, diante de orçamento detalhado, considerando 
os preços praticados no mercado; a definição dos métodos; a estratégia de suprimento e o prazo de execução do contrato. Já o Decreto n $5.450 / 05$ evidencia que o termo de referência deve fazer a indicação do objeto de forma precisa, suficiente e clara, vedadas especificações que, por excessivas, irrelevantes ou desnecessárias, limitem ou frustrem a competição ou sua realização.

Olivo (2012) explica que a licitação pública inicia com a fase interna, momento em que a administração define o objeto e todas as demais condições para elaboração do instrumento convocatório. O procedimento licitatório inicia com a requisição do objeto. É a partir da necessidade, manifestada pelo requerente, que a administração inicia o processo visando à futura contratação.

Ainda nesse sentido, para Batista e Maldonado (2008), os agentes públicos responsáveis pelas instruções dos processos licitatórios devem estar cientes de que, para garantir a perfeita aquisição dos bens ou serviços necessários, torna-se necessário e imprescindível o fornecimento da especificação completa do bem, a definição das unidades e das quantidades a serem adquiridas. Para Meirelles (2006, p. 134), “[...] deve ser indicado no edital por descrição sucinta e clara, que possibilite aos interessados o perfeito conhecimento do que a Administração deseja contratar".

O artigo 14 da Lei no 8.666/93 estabelece que nenhuma compra será feita sem a adequada caracterização de seu objeto e indicação dos seus recursos orçamentários para seu pagamento, sob pena de nulidade do ato e responsabilidade de quem Ihe tiver dado causa.

Todas as demais exigências inseridas no instrumento convocatório dependem da definição do objeto, devendo ser apresentadas de modo compatível e proporcional a ele. Sendo assim, o objeto deve ser muito bem definido para que a licitação tenha sucesso, pois não adianta a administração proceder com uma licitação formalmente correta se as especificações e detalhes do objeto não forem adequados (BOSELLI, 2002).

Para Justen Filho (2013), as licitações de tipo menor preço não excluem exigências de qualidade mínima, ou seja, selecionar a proposta mais vantajosa envolve também uma avaliação da qualidade mínima do objeto. Nesse sentido, Santana (2015) evidencia que a análise do objeto deve resgatar questões mais abrangentes, como é o caso da própria qualidade do gasto público em si, evitando desperdícios e desnecessidades. 
O valor estimado é peça fundamental no processo licitatório, servindo de balizador para classificação das propostas e para aceitação, caso o valor da proposta esteja dentro do estimado, ou ainda visando à desclassificação, caso o valor da proposta esteja muito abaixo ou muito acima do valor estimado. Segundo o Manual do Pregão Eletrônico do Tribunal de Contas da União, a pesquisa de preços não pode ser efetuada por meio de mera coleta. A estimativa deve ser definida através de análise criteriosa que possibilite a constatação de que o preço estimado reflete o praticado no mercado.

Niebuhr e Guimarães (2008) descrevem que:

O orçamento daquilo que se está licitando é ato fundamental para a condução de todo processo, especialmente para proceder ao controle dos preços propostos à Administração, se excessivos ou inexequíveis. Sem o orçamento, sem saber o quanto custa o que se está licitando, a Administração não dispõe de elementos para realizar tais controles, e, por consequência, passa a aceitar quaisquer tipos de valores, em detrimento ao interesse público (NIEBUHR; GUIMARÃES, 2008, p. 153).

Os autores concluem que, com a especificação do objeto, orçamento detalhado de acordo como os preços de mercado, métodos, estratégia de suprimentos e cronograma, inicia-se a elaboração do instrumento convocatório (NIEBUHR; GUIMARÃES, 2008).

O instrumento convocatório (edital) é a ferramenta pela qual a administração leva ao conhecimento público a licitação, estabelecendo todas as regras, tanto para o agente público, quanto para os interessados em participar do certame. Niebuhr (2012) explica que o instrumento convocatório estabelece as regras sobre o certame e é o meio para dar publicidade e convocar os interessados para oferecerem suas propostas.

Justen Filho (2005) afirma que é problemática uma definição abrangente de todo o conteúdo possível do edital. Nele, há quatro núcleos fundamentais, cuja inexistência acarreta a invalidade do ato. Nesses termos, para o autor, um edital deve, necessariamente, conter disciplina sobre o procedimento a ser adotado na licitação; as condições de participação dos interessados no certame; os critérios de seleção da proposta mais vantajosa; e a futura contratação, inclusive com a minuta do contrato.

A Lei no 8.666/93 estabelece ainda, em seu artigo 41, que "a Administração não pode descumprir as normas e as condições do edital, ao qual se acha estritamente vinculada". Nesse mesmo sentido, Justen Filho (2012) explica que: 
O estrito cumprimento aos procedimentos e às regras contidas no ato convocatório é um dever para a Administração, cuja observância pode ser exigida pelos licitantes. Como o ato convocatório estabelece regras de conduta para a Administração, isso produz efeitos reflexos para os licitantes. Permite-lhes prever a conduta futura dos agentes da Administração e, desse modo, orientar as decisões a tomar (JUSTEN FILHO, 2012, p. 592).

A partir da elaboração do edital, todos os demais procedimentos integrantes do processo licitatório estarão vinculados a ele, da mesma forma que os agentes públicos e licitantes estão sujeitos às regras e condições nele estabelecidas. "Assim sendo, uma vez publicado o instrumento convocatório, a Administração e os licitantes estão vinculados a ele, não podendo se apartar ou se divorciar dos seus termos" (NIEBUHR, 2012, p. 253).

Observando o princípio da vinculação ao instrumento convocatório, a administração só poderá exigir aquilo que está prescrito em edital, assim como os licitantes devem apresentar as propostas e documentos nos exatos termos estabelecidos no instrumento convocatório.

Observa-se, então, que a fase preparatória, ou interna, é de extrema importância no processo licitatório, havendo a necessidade de um maior envolvimento de técnicas e práticas administrativas por parte dos servidores públicos que atuam no processo, e é neste momento que se verifica a complexidade de tal processo para as instituições públicas (SANTANA, 2015).

Importante destacar também que, na fase preparatória do certame, deverá ser realizada a designação do pregoeiro e da equipe de apoio por meio de ato administrativo específico, exarado pela autoridade competente (GASPARINI, 2009).

No pregão, seja na forma presencial ou eletrônica, o agente responsável pela condução dos procedimentos necessários para a realização do certame é o pregoeiro. Como nem sempre terá o conhecimento técnico necessário para aceitação dos itens licitados, recomenda-se que a equipe de apoio seja composta por representantes da unidade requerente. "A Administração deverá organizar serviços destinados a apoiar a atividade do pregoeiro. Daí a referência de uma 'equipe de apoio', cuja existência é indispensável para o sucesso do pregão" (JUSTEN FILHO, 2013, p. 96). 
Ressalta-se ainda que, no caso de uma decisão tomada pelo pregoeiro de forma equivocada, embasada em parecer técnico do membro da equipe de apoio, "tal membro deve ser responsabilizado administrativamente, mediante processo administrativo e pode responder subsidiariamente junto ao Tribunal de Contas ou ao Poder Judiciário" (NIEBUHR; GUIMARÃES, 2008, p. 126). Os agentes públicos devem participar mais ativamente, não só do ponto de vista da execução do trabalho, mas também do comportamento ético e moral durante todo o processo licitatório.

Dessa forma, apesar de não terem o poder decisório individual, os membros da equipe de apoio estão sujeitos às regras gerais acerca de responsabilidade civil, penal e administrativa, sendo responsáveis por todas as ações que praticarem no âmbito de suas atividades. O comportamento ético por parte dos compradores públicos é esperado e requerido pela sociedade, com forte alinhamento com o conceito de moral (BATISTA; MALDONADO, 2008).

O Tribunal de Contas da União (2010) evidencia que, durante a fase interna da licitação, a administração poderá corrigir as falhas verificadas no procedimento, sem anular os atos praticados. Porém, após a publicação do edital (fase externa), qualquer falha ou irregularidade constatada, se for insanável, resultará na anulação do procedimento. Caso isso ocorra, novas publicações e contagens de prazos devem ser feitas.

De acordo com o artigo 4ㅇ da Lei no 10.520/02, a fase externa da licitação consiste na publicação do edital; na sessão pública, a qual contempla: credenciamento, classificação das propostas, fase de lances, melhor oferta, direito de preferência, negociação, habilitação, declaração de vencedor, recurso, adjudicação e ata, e homologação. E conforme artigo 17 do Decreto no 5.450/05, “a fase externa do pregão, na forma eletrônica, será iniciada com a convocação dos interessados por meio de publicação de aviso, observados os valores estimados para contratação e os meios de divulgação".

Após publicado o aviso do edital no Diário Oficial da União e, quando for o caso, em jornal de grande circulação local, e passados, no mínimo, os 8 dias úteis, será aberta a sessão pública no dia e horário marcados. A sessão pública dos pregões eletrônicos na esfera federal é realizada no sistema de compras eletrônicas do Governo Federal Comprasnet. 
Salienta-se que a utilização do Comprasnet é obrigatória para órgãos da administração federal direta, autárquica e fundacional que integram o Sisg. Já os órgãos estaduais, municipais e mesmo as entidades da administração federal indireta poderão utilizar seus próprios sistemas de pregão eletrônico ou de outros órgãos.

Por outro lado, havendo interesse em aderir ao sistema federal, basta entrar no portal de compras públicas, http://www.comprasnet.gov.br/, acessar o menu legislação portaria $\mathrm{n}$ o 4 - e preencher o Anexo no I, disponível no documento.

As estruturas procedimentais do pregão eletrônico e presencial são praticamente as mesmas. A diferença está na sessão pública. No presencial, a sessão pública conta com a presença física dos licitantes, diferente do eletrônico, em que a participação dos interessados é realizada virtualmente (OıIvo, 2012).

Gasparini (2009) ressalta que é competência da administração pública, em todos os níveis, perceber a importância desse processo e utilizar de forma responsável os mecanismos disponíveis, sem se desviar dos objetivos fundamentais da licitação, mesmo sabendo que fatores externos podem desfazer a seriedade e lisura do certame virtual. $\mathrm{O}$ Tribunal de Contas da União (2010) esclarece que:

Por mais urgência que se tenha na realização de procedimento licitatório, não se pode admitir que uma fase ultrapasse outra. Qualquer que seja a modalidade de licitação, não poderá ser declarado o vencedor antes de concluídas todas as etapas e observados os prazos de divulgação, impugnação, interposição de recursos etc. (TRIBUNAL DE CONTAS DA UNIÃo, 2010, p. 324).

A licitação deve ser utilizada não apenas para adquirir bens e serviços a um menor preço, mas, além de servir de instrumento para o atendimento de outras finalidades públicas, servir também como instrumento de implantação de políticas públicas. "Uma boa decisão pública é aquela embasada em informações e análises confiáveis, pautadas em princípios e valores aceitos e que traz os efeitos desejados para a melhoria do bemestar social" (Secchi, 2016, p 4).

Para Ferrer (2012), as compras públicas são consideradas um dos processos mais transversais do setor público, o que permite aumentar seu poder transformador quando são inovadas e otimizadas. A incorporação de técnicas e rotinas auxilia na melhoria da 
capacidade gerencial e administrativa, tornando a administração pública mais eficaz e comprometida.

\section{Metodologia}

A natureza da pesquisa é aplicada no tocante à necessidade de se resolver problemas concretos e com finalidade prática. Para Gil (2002), esse tipo de pesquisa representa estudos elaborados com o intuito de resolver problemas identificados no âmbito da realidade em que os pesquisadores atuam ou vivenciam, neste caso, no âmbito dos Departamentos de Compras e de Licitações, vinculados à Pró-Reitoria de Administração da UFSC.

Quanto à caracterização, o estudo possui abordagem qualitativa, valorizando o contato direto da pesquisadora com o ambiente e a situação que está sendo estudada (Godoy, 1995), pois o objetivo é compreender as causas de cancelamento de itens nos pregões eletrônicos, as particularidades do objeto analisado e as percepções dos profissionais que realizam procedimentos relacionados aos processos licitatórios de materiais de consumo.

A classificação da pesquisa, quanto aos fins, é descritiva, haja vista que os procedimentos relacionados à realização de processos licitatórios visando à aquisição de materiais de consumo são apresentados e interpretados. A pesquisa descritiva procura conhecer a realidade estudada, suas características e seus problemas. Pretende descrever com exatidão os fatos e fenômenos de determinada realidade (TRIVIÑOS, 1987).

Em relação aos meios, utilizou-se a pesquisa de campo, bibliográfica e documental. Ademais, com a pesquisa de campo foi possível analisar o fluxo e as características dos processos licitatórios executados na UFSC que motivam o cancelamento de itens em pregões eletrônico direcionados à aquisição de materiais de consumo. A pesquisa de campo "[...] é a investigação empírica realizada no local onde ocorre ou ocorreu o fenômeno ou que dispõe de elementos para explicá-lo" (VERGARA, 2010, 43).

A pesquisa bibliográfica abrange a bibliografia já publicada sobre o tema de estudo. Em termos genéricos, entende-se que a pesquisa bibliográfica é um conjunto 
de conhecimentos reunidos em obras de toda natureza, com a finalidade de conduzir o leitor à pesquisa de determinado assunto, proporcionando o saber (FACHIN, 2006). A pesquisa bibliográfica é caracterizada, neste estudo, pela revisão de literatura relacionada ao estudo de pregões eletrônicos e à análise dos trabalhos acadêmicos publicados acerca da temática.

Foi realizada pesquisa documental, pois a coleta de dados, em uma das etapas, se deu por meio da análise dos processos licitatórios de material de consumo executados pelo Departamento de Licitações da UFSC, desde sua criação, em janeiro de 2014, até dezembro de 2018. Vergara (2010) evidencia que a investigação documental é realizada em documentos conservados no interior de órgãos públicos e privados de qualquer natureza. Dados secundários também foram consultados, como manuais e relatórios divulgados pelos Departamentos de Compras e de Licitações da UFSC.

Com relação às técnicas e instrumentos de coletas de dados, foram utilizados como fonte de dados primários os processos licitatórios realizados pela UFSC, na modalidade de pregão eletrônico, visando à aquisição de material de consumo, no período de 2014 a 2018, e um questionário aplicado aos servidores do Departamento de Compras e de Licitações.

No que se refere aos procedimentos de coleta de dados, foi feito um levantamento junto à planilha de movimentação processual ${ }^{1}$ do Departamento de Licitações da UFSC para seleção dos processos que foram analisados; consulta aos editais desses processos para coleta das descrições, quantidades e valores dos itens; e acesso ao sistema Comprasnet, no qual foi possível consultar as atas dos pregões eletrônicos selecionados, visando identificar cada motivo de cancelamento.

Considerando a quantidade de pregões de materiais de consumo realizados no horizonte temporal de 2014 a 2018, optou-se por analisar uma amostra de pregões que representassem $81 \%$ do total de itens cancelados, por ano. Em uma planilha, os pregões foram ordenados em relação à quantidade de itens cancelados, da maior quantidade para a menor. Na sequência, é apresentada a Tabela 1, que exemplifica como foi definida a representatividade de pregões a serem analisados. O exemplo refere-se ao ano de 2014.

\footnotetext{
${ }^{1}$ A planilha de movimentação processual do DPL consiste no registro de informação referente ao número do pregão, número do processo, unidade requerente, objeto, data de abertura do certame, valor licitado, quantidade licitada, homologada e cancelada, entre outas informações. Além de ser um quadro de indicadores e de transparência.
} 
Tabela 1 | Definição da amostra de pregões realizados em 2014, analisados na pesquisa

\begin{tabular}{|cccccccc}
$\begin{array}{c}\text { No do } \\
\text { Edital }\end{array}$ & $\begin{array}{c}\text { Itens } \\
\text { licitados }\end{array}$ & $\begin{array}{c}\text { Valor } \\
\text { estimado } \\
\text { (R\$) }\end{array}$ & $\begin{array}{c}\text { Valor } \\
\text { adjudicado } \\
\text { (R\$) }\end{array}$ & $\begin{array}{c}\text { Itens } \\
\text { homolo- } \\
\text { gados }\end{array}$ & $\begin{array}{c}\text { Itens } \\
\text { cancelados }\end{array}$ & $\begin{array}{c}\text { \% itens } \\
\text { cancelados }\end{array}$ & $\begin{array}{c}\text { \% Acumulado } \\
\text { de itens } \\
\text { cancelados }\end{array}$ \\
\hline $175 / 2014$ & 204 & $2.150 .863,63$ & $986.466,88$ & 140 & 64 & $15,80 \%$ & $15,80 \%$ \\
\hline $074 / 2014$ & 59 & $617.989,64$ & $397.122,87$ & 27 & 32 & $7,90 \%$ & $23,70 \%$ \\
$254 / 2014$ & 55 & $71.811,92$ & $30.036,59$ & 24 & 31 & $7,65 \%$ & $31,36 \%$ \\
$245 / 2014$ & 93 & $326.184,63$ & $215.677,87$ & 64 & 29 & $7,16 \%$ & $38,52 \%$ \\
$145 / 2014$ & 57 & $16.371,91$ & $11.718,67$ & 31 & 26 & $6,42 \%$ & $44,94 \%$ \\
$142 / 2014$ & 117 & $183.139,86$ & $126.297,23$ & 98 & 19 & $4,69 \%$ & $49,63 \%$ \\
$253 / 2014$ & 176 & $25.656,47$ & $20.694,78$ & 158 & 18 & $4,44 \%$ & $54,07 \%$ \\
$332 / 2014$ & 54 & $126.728,69$ & $89.403,61$ & 36 & 18 & $4,44 \%$ & $58,52 \%$ \\
$073 / 2014$ & 39 & $60.696,45$ & $43.578,11$ & 23 & 16 & $3,95 \%$ & $62,47 \%$ \\
$099 / 2014$ & 20 & $80.300,58$ & $28.500,00$ & 5 & 15 & $3,70 \%$ & $66,17 \%$ \\
$284 / 2014$ & 81 & $258.962,90$ & $196.689,10$ & 68 & 13 & $3,21 \%$ & $69,38 \%$ \\
$141 / 2014$ & 63 & $39.623,87$ & $29.217,28$ & 51 & 12 & $2,96 \%$ & $72,35 \%$ \\
$146 / 2014$ & 30 & $84.284,01$ & $63.492,30$ & 20 & 10 & $2,47 \%$ & $74,81 \%$ \\
$143 / 2014$ & 51 & $32.876,21$ & $24.784,96$ & 42 & 9 & $2,22 \%$ & $77,04 \%$ \\
$088 / 2014$ & 41 & $461.852,71$ & $338.575,60$ & 33 & 8 & $1,98 \%$ & $79,01 \%$ \\
$350 / 2014$ & 82 & $35.144,19$ & $23.434,86$ & 74 & 8 & $1,98 \%$ & $80,99 \%$ \\
\hline $081 / 2014$ & 26 & $18.289,49$ & $13.703,33$ & 19 & 7 & $1,73 \%$ & $82,72 \%$ \\
\hline
\end{tabular}

Fonte: elaboração própria a partir dos dados da pesquisa (2019).

Cabe destacar que o número total de pregões em 2014 foi de 47, totalizando 405 itens cancelados. Contudo, na Tabela 1 é apresentada uma amostra de 17 pregões, que representam 328 itens cancelados, ou $81 \%$ dos itens. 0 percentual dos itens cancelados acumulados foi calculado a partir do total itens calculados, ou seja, 405. A partir da última linha destacada na cor cinza, ou seja, os demais 30 editais realizados em 2014, a representatividade dos pregões que tiveram itens cancelados é muito pequena em comparação com os pregões apresentados nas linhas brancas.

Desse modo, do edital no 175/2014 (primeira linha) até o edital no 350/2014 (penúltima linha), há uma representatividade de $80 \%$ dos itens cancelados no ano de 2014, referentes aos materiais de consumo, sendo estes os processos analisados neste estudo.

A partir dessa definição de $80 \%$ de representatividade, foram analisados 225 processos licitatórios realizados nos anos de 2014 a 2018, totalizando 4.041 itens cancelados, cujos motivos foram identificados e analisados. 
Também foi aplicado um questionário, enviado por e-mail, com quatro perguntas abertas, a um total de 24 servidores do Departamento de Compras e do Departamento de Licitações, envolvidos nas fases interna e externa da licitação, a fim de identificar e/ ou trazer novas evidências acerca dos possíveis fatores que influenciam no cancelamento de itens. Responderam à pesquisa 14 servidores, cujo anonimato foi garantido, sendo todos codificados como "S" (servidor) somando a um número aleatório para cada um dos servidores.

Dentre os 14 servidores que aceitaram participar da pesquisa, dez atuam em cargos de nível médio, como assistentes em administração e técnicos em contabilidade; um atua em cargo de nível fundamental; e três servidores atuam em cargos de nível superior. Em relação às funções exercidas na UFSC, os respondentes atuam como diretores de departamento, coordenadores de compras, pregoeiros, chefes de divisão ou não possuem função gratificada.

Os dados coletados por meio do questionário foram analisados pela pesquisadora utilizando análise de conteúdo, agrupando as respostas de acordo com as similaridades. Os dados coletados do sistema Comprasnet, dos editais e da planilha de movimentação processual do Departamento de Licitações foram registrados em uma planilha do Excel e analisados por meio de análise qualitativa, também realizando categorização dos dados coletados por similaridade.

\section{Resultados}

Foi realizado um levantamento acerca dos motivos que levaram ao cancelamento de itens nos pregões eletrônicos de materiais de consumo, realizados nos anos de 2014 a 2018, pelo Departamento de Licitações da UFSC (DPL). Também foram identificadas as unidades da UFSC que requisitaram tais itens e, consequentemente, não puderam adquirilos devido ao cancelamento, bem como os tipos de materiais cancelados.

No período de 2014 a 2018, de um total de 695 processos licitatórios de material de consumo, realizados sob a modalidade de pregão eletrônico, regulamentada pelo Decreto no 5.450/2005, 514 tiveram itens cancelados, somando-se um total de 5.037 
itens cancelados. Esses 514 pregões eletrônicos visavam adjudicar um total de 17.913 itens. Portanto, constatou-se que, nesse período, houve um registro de $28,12 \%$ de itens cancelados em relação ao total de itens licitados.

Como mencionado no capítulo referente ao delineamento metodológico, foram incluídos 225 pregões eletrônicos na análise do cancelamento de itens, sendo este um recorte que representa $80 \%$ do total de itens cancelados no período investigado. Nesses 225 processos de pregão eletrônico, foram cancelados 4.041 itens de um total de 9.872 itens previamente estimados pela administração, representando 40,93\% de itens cancelados. Em relação ao total de itens pertencentes aos editais de licitação analisados neste estudo, ou seja, a quantidade estimada total de itens, comparados ao total de itens cancelados, apresenta-se a seguinte distribuição, por ano (Tabela 2):

Tabela 2 | Relação entre a quantidade estimada de itens a serem licitados e a quantidade de itens cancelados

\begin{tabular}{rcccccc|} 
Ano & $\begin{array}{c}\text { Total de } \\
\text { Processos }\end{array}$ & $\begin{array}{c}\text { Total de } \\
\text { itens } \\
\text { licitados }\end{array}$ & $\begin{array}{c}\text { Total de } \\
\text { itens } \\
\text { cancelados }\end{array}$ & $\begin{array}{c}\text { Total de } \\
\text { processos } \\
\text { analisados }\end{array}$ & $\begin{array}{c}\text { Total de itens } \\
\text { licitados - } \\
\text { processos } \\
\text { analisados }\end{array}$ & $\begin{array}{c}\text { Total de itens } \\
\text { cancelados }\end{array}$ \\
\hline $\mathbf{2 0 1 4}$ & 90 & 1.942 & 405 & 16 & 1.222 & 328 \\
processos \\
analisados
\end{tabular}

Fonte: elaboração própria a partir dos dados da pesquisa (2019).

Observa-se que o número de itens licitados foi maior no ano de 2018, com 3.342 itens. Consequentemente, este também foi o ano com maior número de itens cancelados, totalizando 1.561, ou 46,71\%, percentual bastante representativo. O ano de 2015 também é um destaque, haja vista que 50,29\% dos itens licitados foram cancelados no decorrer do processo licitatório, ou seja, havia a previsão de licitar 873 itens, no entanto 439 foram cancelados por motivos diversos.

Foram consideradas, também, as unidades da UFSC que demandaram os itens cancelados, analisados neste estudo. As unidades estão ordenadas na Tabela 3 pela quantidade de itens cancelados, em ordem decrescente, considerando o somatório 
dos anos 2014 a 2018. Desse modo, essas unidades da UFSC possuíam a previsão de adquirir determinados itens e tal previsão não logrou êxito em sua totalidade, o que pode ter prejudicado o bom andamento dos serviços prestados, relacionados direta e/ou indiretamente às atividades de ensino, pesquisa e extensão da UFSC.

Tabela 3 | Frequência de cancelamento de itens, distribuídos por ano e unidade requerente

\begin{tabular}{|c|c|c|c|c|c|c|c|c|c|c|c|c|}
\hline \multirow[b]{2}{*}{ Unidade } & \multicolumn{2}{|c|}{2014} & \multicolumn{2}{|c|}{2015} & \multicolumn{2}{|c|}{2016} & \multicolumn{2}{|c|}{2017} & \multicolumn{2}{|c|}{2018} & \multicolumn{2}{|c|}{ TOTAL } \\
\hline & $\begin{array}{c}\text { Itens } \\
\text { licita- } \\
\text { dos }\end{array}$ & $\begin{array}{l}\text { Itens } \\
\text { can- } \\
\text { cela- } \\
\text { dos }\end{array}$ & $\begin{array}{c}\text { Itens } \\
\text { licita- } \\
\text { dos }\end{array}$ & $\begin{array}{l}\text { Itens } \\
\text { cance- } \\
\text { lados }\end{array}$ & $\begin{array}{c}\text { Itens } \\
\text { licita- } \\
\text { dos }\end{array}$ & $\begin{array}{l}\text { Itens } \\
\text { cance- } \\
\text { lados }\end{array}$ & $\begin{array}{c}\text { Itens } \\
\text { licita- } \\
\text { dos }\end{array}$ & $\begin{array}{l}\text { Itens } \\
\text { cance- } \\
\text { lados }\end{array}$ & $\begin{array}{c}\text { Itens } \\
\text { licita- } \\
\text { dos }\end{array}$ & $\begin{array}{l}\text { Itens } \\
\text { cance- } \\
\text { lados }\end{array}$ & $\begin{array}{c}\text { Itens } \\
\text { licita- } \\
\text { dos }\end{array}$ & $\begin{array}{c}\text { Itens } \\
\text { cance- } \\
\text { lados }\end{array}$ \\
\hline CBS & 172 & 50 & 232 & 113 & 385 & 178 & 636 & 235 & 444 & 187 & 1.869 & 763 \\
\hline BLU & 82 & 8 & 91 & 64 & 259 & 124 & 135 & 37 & 553 & 222 & 1.120 & 455 \\
\hline CCA & 120 & 35 & 172 & 95 & 112 & 38 & 211 & 77 & 450 & 199 & 1.065 & 444 \\
\hline CCS & 41 & 8 & 40 & 27 & 70 & 43 & 442 & 154 & 446 & 133 & 1.039 & 365 \\
\hline NDI & 257 & 31 & 193 & 78 & 197 & 109 & 100 & 45 & 70 & 42 & 817 & 305 \\
\hline CCB & 210 & 59 & 63 & 31 & 111 & 45 & 102 & 25 & 216 & 91 & 702 & 251 \\
\hline СТС & 0 & 0 & 0 & 0 & 0 & 0 & 51 & 13 & 313 & 219 & 364 & 232 \\
\hline NUMA & 0 & 0 & 0 & 0 & 0 & 0 & 88 & 17 & 318 & 179 & 406 & 196 \\
\hline CFM & 0 & 0 & 0 & 0 & 43 & 9 & 137 & 103 & 126 & 68 & 306 & 180 \\
\hline PU & 224 & 79 & 49 & 15 & 61 & 8 & 212 & 51 & 16 & 9 & 562 & 162 \\
\hline CFH & 57 & 26 & 0 & 0 & 69 & 22 & 68 & 26 & 102 & 82 & 296 & 156 \\
\hline DMPI & 0 & 0 & 0 & 0 & 0 & 0 & 192 & 70 & 86 & 24 & 278 & 94 \\
\hline CA & 0 & 0 & 0 & 0 & 119 & 57 & 34 & 15 & 43 & 14 & 196 & 86 \\
\hline $\begin{array}{c}\text { SECAR- } \\
\text { TE }\end{array}$ & 0 & 0 & 0 & 0 & 30 & 15 & 0 & 0 & 67 & 49 & 97 & 64 \\
\hline JOI & 0 & 0 & 0 & 0 & 81 & 50 & 92 & 8 & 0 & 0 & 173 & 58 \\
\hline $\mathrm{RU}$ & 0 & 0 & 0 & 0 & 55 & 11 & 173 & 43 & 0 & 0 & 228 & 54 \\
\hline DCOM & 0 & 0 & 0 & 0 & 0 & 0 & 38 & 34 & 0 & 0 & 38 & 34 \\
\hline ARA & 0 & 0 & 0 & 0 & 0 & 0 & 0 & 0 & 64 & 34 & 64 & 34 \\
\hline SEOMA & 0 & 0 & 0 & 0 & 0 & 0 & 55 & 33 & 0 & 0 & 55 & 33 \\
\hline IU & 59 & 32 & 0 & 0 & 0 & 0 & 0 & 0 & 0 & 0 & 59 & 32 \\
\hline $\mathrm{BIC}$ & 0 & 0 & 0 & 0 & 29 & 10 & 0 & 0 & 0 & 0 & 29 & 10 \\
\hline CCE & 0 & 0 & 33 & 16 & 0 & 0 & 0 & 0 & 0 & 0 & 33 & 16 \\
\hline CED & 0 & 0 & 0 & 0 & 0 & 0 & 0 & 0 & 28 & 9 & 28 & 9 \\
\hline IU & 0 & 0 & 0 & 0 & 48 & 8 & 0 & 0 & 0 & 0 & 48 & 8 \\
\hline
\end{tabular}

Fonte: elaboração própria a partir dos dados da pesquisa (2019).

Conforme Tabela 3, a unidade da UFSC com maior número de itens licitados e 
cancelados no período de 2014 a 2018 foi o campus de Curitibanos. Do total de 1.869 itens licitados, 763 foram cancelados, o que representou $40,82 \%$ de cancelamentos.

Além de figurar como a unidade com mais itens cancelados no somatório dos cinco anos analisados, Curitibanos também é um destaque nos anos de 2015, 2016 e 2017. No campus são ofertados os cursos de graduação de Engenharia Florestal, Agronomia, Medicina Veterinária e programa de pós-graduação em Ecossistemas Agrícolas e Naturais. Desse modo, o cancelamento dessa parcela significativa de itens pode influenciar no desenvolvimento do campus e do processo formativo ofertado.

Na segunda colocação em relação ao total de itens licitados e cancelados entre 2014 e 2018, destaca-se o campus de Blumenau, haja vista que, dos 1.120 itens licitados, 455 foram cancelados.

O campus de Blumenau foi criado em 2013, com início das atividades em 2014. Por esse motivo, percebe-se um aumento na quantidade de itens licitados no decorrer dos anos analisados, sendo em 2018 a unidade com maior quantidade de itens licitados e cancelados, 553 e 222, respectivamente.

Portanto, o campus destaca-se na segunda colocação em relação ao número de itens cancelados no período analisado e, também, como a unidade da UFSC com maior número de itens cancelados em 2018. O campus oferta, atualmente, os cursos de graduação de Engenharia de Controle e Automação, Engenharia de Materiais, Engenharia Têxtil, Licenciatura em Matemática e Licenciatura em Química, especialização em Educação Escolar Contemporânea e mestrado em Nanociência, Processos e Materiais Avançados, em Engenharia Têxtil, em Ensino de Física e mestrado profissional em Matemática em Rede Nacional.

Cabe destacar que a complexidade para a construção dos certames dos itens cancelados e a ausência de expertise dos servidores envolvidos no processo licitatório nos campi da UFSC, principalmente Curitibanos e Blumenau, podem representar alguns dos motivos que levaram ao alto índice de cancelamento nesses locais.

As demais unidades da UFSC com itens cancelados, também apresentadas na Tabela 3, não serão evidenciadas no texto, em sua totalidade. No entanto, é importante mencionar que, apesar de não figurar entre as unidades da UFSC que mais tiveram itens 
cancelados, a Prefeitura Universitária (PU) foi um destaque no ano de 2014, apresentando 79 itens cancelados, de um total de 224 itens licitados. A PU/UFSC, integrante da Secretaria de Obras, Manutenção e Ambiente, (Seoma) é composta pelo Departamento de Manutenção Predial e de Infraestrutura, Núcleo de Manutenção, Coordenadoria de Apoio Administrativo e Coordenadoria de Manutenção de Áreas Verdes.

Na sequência, os itens cancelados nos processos licitatórios analisados foram agrupados em categorias, por tipo de material de consumo, conforme Tabela 4.

Tabela 4 | Distribuição das categorias de itens cancelados por ano

\begin{tabular}{|c|c|c|c|c|c|c|}
\hline Categorias & 2014 & 2015 & 2016 & 2017 & 2018 & TOTAL \\
\hline Material de laboratório & 135 & 229 & 312 & 325 & 469 & 1470 \\
\hline Material elétrico & 64 & 0 & 52 & 68 & 74 & 258 \\
\hline Gêneros alimentícios & 13 & 49 & 94 & 45 & 47 & 248 \\
\hline Material de manutenção predial & 35 & 15 & 7 & 60 & 131 & 248 \\
\hline Ferramentas & 7 & 2 & 42 & 71 & 61 & 183 \\
\hline Material pedagógico & 18 & 14 & 69 & 23 & 50 & 174 \\
\hline EPI & 1 & 15 & 5 & 65 & 55 & 141 \\
\hline Material agropecuário & 19 & 50 & 0 & 21 & 28 & 118 \\
\hline Material de uso veterinário & 0 & 44 & 22 & 0 & 48 & 114 \\
\hline Material de expediente & 5 & 0 & 13 & 26 & 56 & 100 \\
\hline Material de acondicionamento e embalagens & 0 & 0 & 10 & 10 & 34 & 54 \\
\hline Material de informática & 0 & 0 & 15 & 26 & 0 & 41 \\
\hline Material gráfico & 32 & 0 & 8 & 0 & 0 & 40 \\
\hline Material de áudiovisual & 0 & 15 & 3 & 19 & 0 & 37 \\
\hline Utensílios de cozinha & 0 & 15 & 0 & 13 & 0 & 28 \\
\hline Gás & 0 & 0 & 0 & 7 & 0 & 7 \\
\hline Material de transporte & 0 & 0 & 1 & 0 & 0 & 1 \\
\hline
\end{tabular}

Fonte: elaboração própria a partir dos dados da pesquisa (2019).

As cinco categorias de material de consumo que apresentaram maior número de itens cancelados no decorrer dos pregões eletrônicos, no somatório dos anos de 2014 a 2018, foram: material de laboratório (1.470 itens), material elétrico (258 itens), gêneros alimentícios (248 itens), itens de manutenção predial (248 itens) e ferramentas (183 itens). O grande destaque, portanto, é para a quantidade de itens cancelados referentes a material de laboratório.

A UFSC possui diversos laboratórios de ensino e pesquisa, nos mais diversos centros 
de ensino, portanto, tal resultado era esperado, justamente pela grande quantidade de itens de laboratório solicitados pelos centros de ensino. Nessa categoria, também estão incluídos os materiais de laboratório licitados para os demais campi da UFSC (Araranguá, Curitibanos, Joinville e Blumenau).

A categoria que contempla os itens referentes a material elétrico inclui os materiais utilizados para manutenção da infraestrutura elétrica, bem como materiais utilizados nos laboratórios de ensino e pesquisa vinculados aos cursos ofertados pela UFSC.

Os gêneros alimentícios, abarcados pela terceira categoria apresentada na Tabela 4, referem-se aos alimentos requeridos pelos setores que atuam junto ao Restaurante Universitário (RU), ao Núcleo de Desenvolvimento Infantil (NDI) e ao Colégio de Aplicação (CA).

Essas três unidades da UFSC realizam seus pedidos de compras junto ao Departamento de Compras da UFSC (DCOM), cujos alimentos, ofertados aos estudantes de graduação, pós-graduação, servidores técnico-administrativos e docentes, estudantes da educação infantil (NDI) e dos ensinos fundamental e médio (CA), passam por processos de licitação, na modalidade de pregão eletrônico. Assim, gêneros alimentícios cancelados nos processos licitatórios deixam de ser adquiridos pela instituição, podendo impactar negativamente a prestação desse tipo de serviço.

As categorias de material de manutenção predial e ferramentas incluem os materiais utilizados para manutenção da infraestrutura da universidade, em geral.

O levantamento dos motivos de cancelamento de itens foi realizado por ano e, posteriormente, os resultados foram agrupados, com a intenção de hierarquizar os motivos, por frequência, no conjunto dos últimos cinco anos, conforme a Tabela 5. 
Tabela 5 | Frequência dos motivos de cancelamento de itens nos pregões eletrônicos entre os anos de 2014 a 2018

\begin{tabular}{|c|c|c|c|c|c|c|c|c|}
\hline $\begin{array}{l}\text { Se- } \\
\text { quen- } \\
\text { cial }\end{array}$ & Motivos dos cancelamentos & 2014 & 2015 & 2016 & 2017 & 2018 & TOTAL & $\begin{array}{l}\text { Percentual } \\
\text { de } \\
\text { representa- } \\
\text { tividade }\end{array}$ \\
\hline 1 & Deserto. & 91 & 145 & 270 & 392 & 923 & 1821 & $38,38 \%$ \\
\hline 2 & $\begin{array}{l}\text { Valor acima do estimado e } \\
\text { fornecedor não aceitou reduzir. }\end{array}$ & 100 & 144 & 273 & 167 & 275 & 959 & $20,21 \%$ \\
\hline 3 & $\begin{array}{l}\text { Valor acima do estimado e } \\
\text { fornecedor não respondeu ao } \\
\text { questionamento feito via chat. }\end{array}$ & 95 & 150 & 76 & 264 & 174 & 759 & $16,00 \%$ \\
\hline 4 & $\begin{array}{l}\text { Proposta não está de acordo com } \\
\text { o edital. }\end{array}$ & 51 & 40 & 50 & 103 & 98 & 342 & $7,21 \%$ \\
\hline 5 & $\begin{array}{l}\text { Fornecedor não respondeu ao } \\
\text { questionamento feito via chat. }\end{array}$ & 67 & 5 & 42 & 115 & 10 & 239 & $5,04 \%$ \\
\hline 6 & $\begin{array}{l}\text { Fornecedor não enviou as } \\
\text { Demonstrações Contábeis. }\end{array}$ & 30 & 5 & 46 & 47 & 59 & 187 & $3,94 \%$ \\
\hline 7 & $\begin{array}{l}\text { Demonstrações Contábeis não } \\
\text { estão de acordo com o exigido em } \\
\text { edital. }\end{array}$ & 33 & 0 & 6 & 73 & 41 & 153 & $3,22 \%$ \\
\hline 8 & $\begin{array}{l}\text { Fornecedor não enviou os } \\
\text { documentos de habilitação. }\end{array}$ & 26 & 10 & 36 & 21 & 9 & 102 & $2,15 \%$ \\
\hline 9 & $\begin{array}{l}\text { Fornecedor com impedimento de } \\
\text { licitar com a União. }\end{array}$ & 7 & 11 & 17 & 10 & 19 & 64 & $1,35 \%$ \\
\hline 10 & $\begin{array}{l}\text { Fornecedor } \\
\text { desclassificação da proposta. }\end{array}$ & 16 & 29 & 2 & 3 & 6 & 56 & $1,18 \%$ \\
\hline 11 & $\begin{array}{l}\text { Fornecedor não enviou os } \\
\text { documentos de aceitação. }\end{array}$ & 10 & 2 & 5 & 8 & 0 & 25 & $0,53 \%$ \\
\hline 12 & $\begin{array}{l}\text { Documentos de aceitação } \\
\text { enviados não estão de acordo com } \\
\text { o edital. }\end{array}$ & 3 & 0 & 7 & 0 & 0 & 10 & $0,21 \%$ \\
\hline 13 & $\begin{array}{l}\text { Itens lançados no sistema com } \\
\text { valores incorretos. }\end{array}$ & 0 & 0 & 0 & 6 & 0 & 6 & $0,13 \%$ \\
\hline 14 & $\begin{array}{l}\text { Documentos de habilitação } \\
\text { enviados não estão de acordo com } \\
\text { o Edital. }\end{array}$ & 0 & 5 & 0 & 0 & 0 & 5 & $0,11 \%$ \\
\hline 15 & Erro na descrição do edital. & 0 & 0 & 3 & 0 & 0 & 3 & $0,06 \%$ \\
\hline 16 & $\begin{array}{l}\text { Fornecedor com impedimento } \\
\text { indireto de licitar com a União. }\end{array}$ & 0 & 0 & 0 & 0 & 3 & 3 & $0,06 \%$ \\
\hline 17 & $\begin{array}{l}\text { As especificações deste item serão } \\
\text { analisadas. }\end{array}$ & 2 & 0 & 0 & 0 & 0 & 2 & $0,04 \%$ \\
\hline 18 & Especificação incompleta. & 0 & 0 & 0 & 2 & 0 & 2 & $0,04 \%$ \\
\hline
\end{tabular}




\begin{tabular}{|c|c|c|c|c|c|c|c|c|}
\hline $\begin{array}{l}\text { Se- } \\
\text { quen- } \\
\text { cial }\end{array}$ & Motivos dos cancelamentos & 2014 & 2015 & 2016 & 2017 & 2018 & TOTAL & $\begin{array}{c}\text { Percentual } \\
\text { de } \\
\text { representa- } \\
\text { tividade }\end{array}$ \\
\hline 19 & $\begin{array}{l}\text { Identificação de vínculo entre } \\
\text { duas empresas participantes do } \\
\text { certame. }\end{array}$ & 0 & 0 & 0 & 2 & 0 & 2 & $0,04 \%$ \\
\hline 20 & $\begin{array}{l}\text { Cancelado por oportunidade e } \\
\text { conveniência da Administração }\end{array}$ & 0 & 0 & 0 & 1 & 0 & 1 & $0,02 \%$ \\
\hline 21 & $\begin{array}{l}\text { Código do item cadastrado no } \\
\text { sistema precisa ser corrigido. }\end{array}$ & 0 & 0 & 1 & 0 & 0 & 1 & $0,02 \%$ \\
\hline 22 & $\begin{array}{l}\text { Item cancelado a pedido da equipe } \\
\text { de apoio. }\end{array}$ & 1 & 0 & 0 & 0 & 0 & 1 & $0,02 \%$ \\
\hline 23 & $\begin{array}{l}\text { Necessidade de adequação da } \\
\text { especificação do item. }\end{array}$ & 0 & 0 & 0 & 0 & 1 & 1 & $0,02 \%$ \\
\hline 24 & Revisar valor estimado. & 0 & 0 & 0 & 1 & 0 & 1 & $0,02 \%$ \\
\hline
\end{tabular}

Fonte: elaboração própria a partir dos dados da pesquisa (2019).

Os motivos de cancelamento de itens que mais se destacam, por ordem de frequência, referem-se à licitação deserta, valor da proposta acima do valor estimado, proposta em desacordo com o edital, ausência de resposta do licitante no chat do sistema Comprasnet, falta de envio de documentação de habilitação contábil, envio de documentação contábil em desacordo com as exigências do edital, fornecedor com impedimento de licitar com a União e não envio da documentação referente à proposta comercial. Esses motivos se coadunam com a literatura no sentido da complexidade e diversidade de fatores que podem justificar o cancelamento de um item, conforme retratado por diferentes autores (Bosseli, 2002; Batista; Maldonado, 2008; Justen Filho, 2013).

Outros motivos foram identificados, porém, com menos de seis ocorrências nos cinco anos analisados. Na sequência, é apresentada uma breve descrição acerca de cada um dos principais motivos de cancelamento de itens, em ordem de frequência.

Itens desertos (1) dizem respeito ao fato de não haver propostas cadastradas, ou seja, nenhum fornecedor demonstrou interesse em disputar tais itens. O ano de 2018 apresentou uma quantidade bastante elevada de itens desertos (923), quando comparado com os demais anos.

Esse resultado era esperado, de certa forma, pois o ano de 2018 foi aquele com maior número de itens licitados, mas a diferença em relação aos anos de 2014 a 2017 é significativa, podendo estar relacionada a motivos que não estão evidenciados nas 
atas de encerramento dos pregões, por exemplo, pouco interesse dos fornecedores em disputarem determinados itens que, porventura, não apresentem grande vantagem.

Conforme dados apresentados na Tabela 5, a negativa acerca da negociação (2) é a segunda razão mais frequente para o cancelamento de itens, seguida da falta de manifestação no chat (3). Nos dois casos, a proposta do licitante deve ser desclassificada por estar com valor superior ao aceitável pela administração, conforme as regras estabelecidas nos editais.

O quarto motivo de cancelamento de itens mais recorrente é desclassificação de propostas em desacordo com o edital (4). Isso ocorre nos casos em que todas as propostas apresentadas para determinado item foram desclassificadas pelo pregoeiro, em parceria com sua equipe de apoio, em decorrência da inadequação das propostas apresentadas quando comparadas com as regras do edital.

É importante ressaltar que o fato de as propostas não estarem de acordo com o edital (342 itens) pode estar relacionado a diferentes aspectos, no entanto não foi possível detalhar as especificidades desse motivo, pois não houve o registro de tal detalhamento em algumas atas de encerramento dos pregões. Nesse sentido, é possível que outras categorias apresentadas na Tabela 5 estejam contempladas por essa categoria maior (proposta não está de acordo com o edital). Em síntese, nota-se que a apresentação de propostas em desacordo com o edital é uma categoria que se refere a produtos ofertados que não estão de acordo com as especificações exigidas em edital.

Outro motivo de cancelamento de itens, identificado durante a análise dos pregões eletrônicos, foi a ausência de respostas dos licitantes ao serem questionados pelo pregoeiro (5), via chat do sistema eletrônico de compras do Governo Federal - Comprasnet.

Esse motivo de cancelamento não é o mesmo mencionado anteriormente, haja vista que a ausência de manifestação mencionada dizia respeito à negociação dos valores propostos. Neste caso específico, o pregoeiro realizou algum questionamento relacionado a aspectos técnicos da proposta ofertada, ou relacionado a alguma documentação, e não houve manifestação do licitante. É importante salientar que, em geral, os pregoeiros disponibilizam um prazo para que o licitante registre manifestação. Por exemplo, ao questionar determinado licitante sobre as especificações do item ofertado, o pregoeiro pode disponibilizar um prazo de 10 minutos para manifestação. 
Nesse caso, se o licitante registrar qualquer mensagem dentro desses 10 minutos e, até mesmo, solicitar um prazo maior para responder ao questionamento, o pregoeiro, em geral, concede esse prazo. O que não pode ocorrer é a ausência total de manifestação, principalmente por estarmos tratando de um processo licitatório realizado de forma eletrônica, que foi concebido justamente para trazer maior celeridade ao processo, conforme o Decreto no 5.450/05.

Acerca da ausência de manifestação aos questionamentos do pregoeiro, também é possível que o licitante não esteja conectado ao chat durante o transcurso da sessão pública, apesar de todas as datas e horários serem amplamente divulgados a todos os participantes.

O não envio de documentos contábeis (6) também foi um dos motivos de cancelamento de itens nos pregões eletrônicos analisados. Até o mês de julho de 2018, para fins de análise da qualificação econômico-financeira das empresas, conforme as regras estabelecidas nos editais da UFSC, era necessário que o licitante apresentasse um resultado igual ou superior a 1,00 (um) em todos os índices que medem a situação financeira (liquidez geral, solvência geral e liquidez corrente).

A partir do mês de julho de 2018, os índices deixaram de ser exigidos no edital dos pregões eletrônicos para aquisição de material de consumo, justamente por estar ocorrendo, com muita frequência, a inabilitação de empresas pelo não envio das demonstrações contábeis ou pelo envio em desacordo com as exigências do edital.

Desse modo, conforme mencionado anteriormente, o envio das demonstrações contábeis em desacordo com as exigências do edital da UFSC (7) também foi um dos principais motivos de cancelamento de itens nos pregões eletrônicos. O envio das demonstrações contábeis era solicitado pelo pregoeiro nos casos em que o fornecedor apresentava os índices financeiros, no Sicaf, inferiores a 1,00, ou tal registro junto ao Sicaf estava vencido.

Conforme previsto em edital, somente eram aceitas as demonstrações contábeis na forma da lei, devendo contemplar: a indicação do número das páginas e do número do livro diário onde estão inscritos o balanço patrimonial e a demonstração do resultado do exercício, acompanhados dos respectivos termos de abertura e encerramento do mesmo; assinatura do contador e do titular ou representante legal da entidade nas demonstrações 
contábeis; e prova de registro na junta comercial ou cartório (com carimbo, etiqueta ou chancela da junta comercial).

O oitavo motivo de cancelamento de itens mais recorrente foi o não envio dos documentos de habilitação² (8), quando solicitados pelo pregoeiro via sistema Comprasnet. São considerados documentos de habilitação: as certidões negativas de débitos federal, estadual, municipal e trabalhista; as demonstrações contábeis (até julho de 2018); e certidões geradas pelo Portal da Transparência, Tribunal de Contas da União e Conselho Nacional de Justiça.

Essas certidões são consultadas pelo pregoeiro, de forma online, mas caso estejam com validade vencida ou não possam ser consultadas por algum motivo técnico, o licitante deve encaminhá-las via sistema, após solicitação do pregoeiro. Outros documentos podem ser solicitados, para fins de habilitação, desde que previstos no edital, como atestados de capacidade técnica, por exemplo.

Fornecedor com impedimento de licitar com a União também motivou o cancelamento de itens entre os anos de 2014 a 2018 (9). Conforme previsto em edital, sendo constatado qualquer impedimento de licitar ou contratar, por parte do fornecedor, nas consultas ao Portal da Transparência, Portal do Conselho Nacional de Justiça ou ainda por meio do cadastro Sicaf, no que se refere à UFSC ou no âmbito da União, o mesmo será inabilitado.

Desse modo, supondo que somente um licitante ofertou proposta para determinado item, ao consultar os documentos de habilitação desse licitante, o pregoeiro constatou que o mesmo está impedido de licitação com a UFSC ou com a União, resultando na inabilitação da empresa.

A desclassificação da proposta, a pedido do licitante (10), também emergiu como um dos motivos de cancelamento de itens. Durante a fase de lances ou na fase de aceitação, por ter cadastrado um valor muito baixo e/ou modelo e marca incorretos, o fornecedor, nesses casos, solicitou a desclassificação de sua proposta.

Em alguns casos, os licitantes não enviaram documentos de aceitação solicitados no edital (11), exigência presente geralmente nos pregões que visam à aquisição de gêneros 
alimentícios, demandando o envio de fichas técnicas dos produtos. O não envio desses documentos, após convocação via sistema Comprasnet, acarreta desclassificação do licitante e, caso não haja outras propostas aceitáveis, o cancelamento do item. Com menor ocorrência (12), houve casos em que o licitante enviou o documento de aceitação previsto no edital, mas não estava de acordo com as exigências, após análise técnica por parte da equipe de apoio, gerando a desclassificação da proposta e consequente cancelamento do item.

Os motivos que emergiram da pesquisa documental, com menor frequência, estão relacionados aos próprios fornecedores, como: documentos de habilitação enviados em desacordo com o edital (14); fornecedor com impedimento indireto de licitar com a União (16); e identificação de vínculo entre duas empresas participantes do certame (19).

Outros motivos, com pouca frequência, estão relacionados a cancelamentos realizados a critério da administração, como: itens lançados no sistema com valores incorretos (13); erro na descrição do edital (15); especificações a serem revisadas (17); especificação incompleta (18); cancelado por oportunidade e conveniência da administração (20); código do item cadastrado no sistema precisa ser corrigido (21); item cancelado a pedido da equipe de apoio (22); necessidade de adequação da especificação do item (23) e revisar valor estimado (24).

Percebe-se que as motivações identificadas nos pregões eletrônicos analisados estão fundamentadas nas regras previstas em edital, ou seja, estão relacionadas ao princípio da vinculação ao instrumento convocatório. Uma vez publicado o edital, agentes públicos e licitantes estão sujeitos às regras nele estabelecidas.

Registram-se ainda, nos relatos dos servidores, fatores como a ausência de manifestação dos licitantes no chat; descrição do objeto ofertado em desacordo com as exigências do edital; valor ofertado superior ao valor estimado pela administração; ausência de fornecedores interessados em participar do certame; equívocos na pesquisa de preços realizada pela administração; e equívocos na descrição dos itens realizada por ela.

O licitante não se manifesta no chat quando questionado pelo pregoeiro; a descrição do produto ofertado não atende ao especificado no edital (instrumento convocatório); item deserto (sem apresentação de proposta); a especificação do 
edital não corresponde à do mercado fornecedor; o valor estimado não é compatível com o mercado fornecedor (valor subestimado) (S3).

Licitante não responde aos questionamentos feitos via chat; valor acima do estimado pela administração, sem o aceite de negociação por parte do licitante; itens desertos (sem registro de propostas); propostas ofertadas não atendem às especificações do objeto, em comparação às exigências do edital. Acredito que estes sejam os principais motivos de cancelamento (S4).

O cancelamento de itens pode ocorrer por 1) ausência de fornecedores interessados em participar do certame; 2 ) itens com descrição e especificação em desacordo com o tipo de material que é ofertado pelo mercado; 3) valores de referência acima do que os fornecedores podem oferecer para o item com mesma especificação; e 4) ausência de participantes do certame que possuam os documentos exigidos para a fase de habilitação (S5).

Observa-se, com as falas S3, S4 e S5, a dificuldade na comunicação entre licitante e pregoeiro, ou ainda a ausência de fornecedores para participação no certame. A seguir, são apresentados outros problemas identificados pelos entrevistados:

Especificação, preço ou ambos (S8).

Problemas de orçamento, problemas de descrição/especificação dos itens, pouca divulgação no caso de itens mais específicos, falta de agrupamento ou conciliação de solicitações a fim de tornar o item "mais atrativo" ao mercado em função do volume (S9).

(a) Pesquisa de preços incongruente, não refletindo a realidade mercadológica; (b) especificações técnicas inconsistentes, descrevendo incorretamente o item que se deseja adquirir; (c) ausência de alocação de equipe responsável por item específico (e.g. pregões com múltiplas equipes); (d) ausência de parecer técnico da equipe de apoio designada acerca da compatibilidade do item ofertado (S10).

Com os entrevistados S8 a S10, observam-se problemas referentes à pesquisa de preços e especificações técnicas, o que pode retratar, por exemplo, uma falta de planejamento na construção do certame, gerando cancelamento do processo licitatório. 
Por fim, é apresentada uma síntese dos principais motivos de cancelamento alocados pelos respectivos respondentes na Tabela 6.

Tabela 6 | Principais motivos de cancelamento

\begin{tabular}{|l|l|}
\hline \multicolumn{1}{|c|}{ Motivos dos cancelamentos } & \multicolumn{1}{|c|}{ Entrevistados } \\
\hline Equívocos na descrição dos itens realizada pela administração & $\begin{array}{l}\text { E1, E3, E4, E5, E6, E7, } \\
\text { E6, E9, E10, E11, E12, E13 }\end{array}$ \\
\hline Equívocos na pesquisa de preços realizada pela administração & $\begin{array}{l}\text { E2, E3, E6, E7, E8, E9, } \\
\text { E10, E11, E12, E13, E14 }\end{array}$ \\
\hline Ausência de manifestação dos licitantes no chat & E3, E4, E6 \\
\hline Descrição do objeto ofertado em desacordo com as exigências do edital & E3, E4, E6, E14 \\
\hline Ausência de fornecedores interessados em participar do certame & E3, E4, E5, E6 \\
\hline Valor ofertado superior ao valor estimado pela administração & E4, E5, E14 \\
\hline Licitantes não possuem os documentos de habilitação & E5, E11 \\
\hline Fonte: elaboração própria a partir dos dados da pesquisa (2019). & \\
\hline
\end{tabular}

Com base na Tabela 6, destacam-se os equívocos na descrição dos itens e pesquisa de preços realizadas pela administração do setor, que foram apontados por todos os 14 entrevistados.

Com a finalidade de evitar ou minimizar os impactos negativos do cancelamento de itens em pregões eletrônicos que visam à aquisição de materiais de consumo, são propostas algumas ações com base nos resultados do estudo, o qual considerou a percepção dos servidores que atuam diretamente em todas as etapas dos processos de compras e licitações da UFSC. Ao serem colocadas em prática, as ações propostas neste estudo poderão aumentar as oportunidades de sucesso dos processos licitatórios, reduzindo e/ou evitando o cancelamento de itens, algo tão comum e, infelizmente, danoso para a administração pública e gestão universitária, visto que interfere diretamente nas atividades finalísticas da instituição.

Assim, como produto deste estudo, são propostas as seguintes ações:

- maior conscientização e comprometimento por parte dos requerentes, já que são os responsáveis pela adequada especificação técnica e pesquisa de preços dos itens que devem ser licitados, sendo esses dois dos aspectos mais relevantes para o sucesso da licitação, conforme resultados apresentados no estudo;

- capacitação e treinamento dos servidores responsáveis pela especificação e pesquisa de preços do objeto licitado, para que tenham conhecimento sobre a importância de cada 
etapa desenvolvida no processo e possam executá-la de forma correta, melhorando a qualidade dos itens adquiridos e a eficiência dos gastos públicos;

- melhorar o planejamento para que haja uma centralização das demandas, evitando que se tenha mais de um processo para o mesmo objeto. Agrupando as compras, aumenta o quantitativo a ser licitado, podendo tornar os pregões mais atrativos aos fornecedores. Essa metodologia está sendo adotada pelo DCOM, a partir de 2019, visando melhorar os resultados no que se refere, entre outros, à diminuição da diversidade de preços registrados para um mesmo item;

- analisar de forma mais criteriosa as descrições e as pesquisas de preços dos itens solicitados, verificando se são compatíveis e estão de acordo com a realidade do mercado;

- ampliar, sempre que possível, o período de publicação dos editais, verificando também a possibilidade de aumentar a divulgação utilizando outros meios de comunicação. Por exemplo, divulgar o edital por meio de mala direta para fornecedores da área, especialmente para os pregões cujos objetos possuem poucos fornecedores;

- penalizar os licitantes quando não enviam a documentação exigida em edital. Necessário que tenham mais atenção quanto à leitura do edital e acompanhamento da(s) sessão(s) pública(s) via sistema Comprasnet, para evitar que itens sejam cancelados por falta de manifestação no chat do sistema Comprasnet e/ou por não envio de documentos; e

- revisão no fluxo de trabalho, aperfeiçoando os processos a partir da gestão de processos. Nesse sentido, sugere-se que pessoas atuem unicamente nessa área, para que de fato possam entendê-lo e aperfeiçoá-lo.

Importante destacar que, no decorrer da pesquisa, foi possível identificar que algumas ações já vêm sendo executadas, visando melhorar os resultados dos processos licitatórios de material de consumo.

A elevada quantidade de itens por processo, alguns casos com mais de 100 itens, diminuía a dinâmica do pregão em sua fase externa, pois os licitantes deixavam de acompanhar as sessões públicas, não respondendo possíveis questionamentos referente à aceitação dos itens ou deixando de enviar documentos exigidos em edital, resultando em um grande número de itens cancelados. Por esse motivo, a quantidade de itens, no geral, por processo foi reduzida a 50 itens.

Realizar ligações telefônicas solicitando que os licitantes acompanhem o chat, quando não respondem aos questionamentos dos pregoeiros, infelizmente ainda é uma prática comum na administração pública, prejudicando a transparência de seus atos.

Para agilizar o andamento dos processos licitatórios de material de consumo, em agosto de 2015, foi emitido um parecer jurídico referencial tornando juridicamente 
possível o prosseguimento dos processos licitatórios sem submeter os autos ao exame e parecer individual da Procuradoria Federal.

O não envio das demonstrações contábeis ou o envio das demonstrações contábeis em desacordo com o edital eram fatores que ocasionavam frequentes inabilitações e, consequentemente, cancelamento de itens. Por esste motivo, a partir do mês de julho de 2018, a análise da qualificação econômico-financeira deixou de ser exigida nos editais de pregão eletrônico para aquisição de material de consumo da UFSC.

À medida que se conhecem os dados e se tem as informações necessárias, as pessoas percebem a realidade sob uma nova perspectiva, permitindo a concepção de novos conhecimentos e buscando ações que contribuam para o desenvolvimento da instituição.

\section{Considerações finais}

O presente estudo analisou os cancelamentos de itens de material de consumo em pregões eletrônicos realizados no âmbito da UFSC, no período de 2014 a 2018.

A partir da identificação das características dos cancelamentos de itens de materiais de consumo em pregões eletrônicos realizados pela UFSC entre os anos de 2014 a 2018, constatou-se que as unidades com maior número de itens cancelados foram os Campi de Curitibanos e Blumenau. Referente às categorias dos itens cancelados, os materiais de laboratórios, materiais elétricos, gêneros alimentícios, materiais de manutenção predial e ferramentas foram as que apresentaram maior ocorrência, podendo ter impactado negativamente no desenvolvimento das atividades de ensino, pesquisa e extensão que demandaram tais objetos.

Os destaques, em ordem de ocorrência, referem-se à licitação deserta, valor da proposta acima do estimado, proposta em desacordo com o edital, ausência de resposta do licitante no chat do sistema Comprasnet, falta de envio de documentação de habilitação contábil, envio de documentação contábil em desacordo com as exigências do edital, fornecedor com impedimento de licitar com a União e não envio da documentação referente à proposta comercial. 
As respostas apresentadas pelos entrevistados com relação aos principais motivos de cancelamento de itens indicaram diversos aspectos que confirmaram os resultados apresentados.

Dessa forma, destaca-se que é necessária a conscientização dos requerentes quanto à importância da instrução processual em sua fase interna, capacitação e treinamento desses servidores, para que possam executar as tarefas de forma correta, e revisão no fluxo de trabalho.

Presume-se ainda que ações de melhorias estão diretamente associadas à mudança de comportamento, e para isso é necessário que se tenha conhecimento sobre os processos e normas que regem as licitações.

Na gestão universitária, assim como na administração pública em geral - haja vista que a pesquisa realizada na UFSC e consequentemente os resultados gerados apontam para características similares compartilhadas por outros órgãos -, as ações propostas poderiam ajudar a formar um ambiente de mudanças constantes que demandam por parte dos servidores públicos dinamicidade e aprendizagem contínua e permanente, para que possam promover um serviço de melhor qualidade.

Nesse aspecto, Batista e Maldonado (2008) corroboram tal entendimento, considerando que novas práticas de gestão, aliadas à difusão da informação e do conhecimento, podem garantir a realização dos objetivos da instituição.

Por fim, destaca-se que na UFSC os departamentos responsáveis pelas fases interna e externa da licitação vêm adotando práticas para aperfeiçoar, dentro da legalidade, os processos licitatórios de material de consumo, buscando, desse modo, melhorar a qualidade dos itens adquiridos, a eficiência dos gastos públicos e possibilitando que a universidade exerça plenamente suas atividades relacionadas ao ensino, à pesquisa e à extensão.

Para estudos futuros, são identificadas lacunas referentes à análise dos cancelamentos de itens em processos licitatórios de serviços, haja vista que seguem outras normativas e possuem especificidades diferentes daquelas de materiais de consumo; e estudos referentes aos cancelamentos de itens nos pregões eletrônicos de itens de material de consumo e de material permanente de modo comparativo. 


\section{Referências bibliográficas}

BATISTA, Marco Antonio Cavalcanti; Maldonado, José Manuel Santos de Varge. O papel do comprador no processo de compras em instituições públicas de ciência e tecnologia em saúde (C\&T/S). Revista de Administração Pública, Rio de Janeiro, v. 42, n. 4, p. 681-699, jul./ago. 2008. Disponível em: <http://bibliotecadigital.fgv.br/ojs/index.php/rap/article/view/6650/5234>. Acesso em: 27 out. 2018.

Bittencourt, Sidney. Pregão eletrônico. 3. ed. ampl. e atual. Belo Horizonte: Fórum, 2010. BOSELLI, P. Simplificando as Licitações. 2. São Paulo: Edicta, 2002.

BRASIL. Constituição da República Federativa do Brasil. Brasília, DF: Senado, 1988. Disponível em <http://www.planalto.gov.br/ccivil_03/constituicao/constituicao.htm>. Acesso em: 15 jun. 2017.

Decreto 3.555, de 08 de agosto de 2000. Aprova o Regulamento para a modalidade de licitação denominada pregão, para aquisição de bens e serviços comuns.Disponível em < http:// www.planalto.gov.br/ccivil_03/decreto/d3555.htm>. Acesso em: 02 jul. 2017.

Decreto 5.450, de 31 de maio de 2005. Regulamenta o pregão, na forma eletrônica, para aquisição de bens e serviços comuns, e dá outras providências. Disponível em < http://www. planalto.gov.br/ccivil_03/_ato2004-2006/2005/decreto/d5450.htm>. Acesso em: 02 jul. 2017.

. Lei 8.666, de 21 de junho de 1993. Regulamenta o pregão, na forma eletrônica, para aquisição de bens e serviços comuns, e dá outras providências. Disponível em <http://www. planalto.gov.br/ccivil_03/leis/L8666cons.htm>. Acesso em: 04 mai. 2017.

. Lei 10.520, de 17 de julho de 2002. Institui, no âmbito da União, Estados, Distrito Federal e Municípios, nos termos do art. 37, inciso XXI, da Constituição Federal, modalidade de licitação denominada pregão, para aquisição de bens e serviços comuns, e dá outras providências. Disponível em <http://www.planalto.gov.br/ccivil_03/leis/2002/L10520.htm>. Acesso 04 mai. 2017.

CoelHo, Paulo Magalhães da Costa. Manual de Direito Administrativo. São Paulo: Saraiva, 2004.

COMPRASNet, Compras Governamentais. Manual Pregão Eletrônico - Pregoeiro parte I. 2006. Disponível em:

<http://www.comprasnet.gov.br/publicacoes/manuais/MANUAL_DO_PREGAO_ELETRONICOPREGOEIRO_JULHO_2006.pdf>. Acesso 10 out. 2018.

DI PIetro, Maria Sylvia Zanella. Direito Administrativo. 26. ed. São Paulo: Atlas, 2013.

FACHIN, Odília. Fundamentos de metodologia. 5. ed. São Paulo: Saraiva, 2006.

Ferrer, Florencia. Compras públicas no Brasil: diagnóstico e desenho estratégico do futuro. 2012. Disponível em: <http://www.florenciaferrer.com.br/>. Acesso 10 out. 2018.

GASPARINI, Diogenes. Pregão presencial e eletrônico. 2. ed., Belo Horizonte: Fórum, 2009. 
GIL, A. C. Como elaborar projetos de pesquisa. 4. ed. São Paulo: Atlas, 2000.

Godoy, A. S. Introdução à pesquisa qualitativa e suas possibilidades. In: Revista de Administração de Empresas, São Paulo, v. 35, n. 2, p. 57-63, abril 1995.

JUNIOR, Jessé Torres Pereira; DOTTI, Marinês Restelatto. Políticas Públicas nas Licitações e Contratações Administrativas. Belo Horizonte: Fórum, 2009.

JUSTEN FILHO, Marçal. Pregão: comentários à legislação do pregão comum e eletrônico. 4. ed. São Paulo: Dialética, 2005.

Pregão: comentários à legislação do pregão comum e eletrônico. 6. ed. São Paulo:

Dialética, 2013.

MeIRelles, Hely Lopes. Licitação e contrato administrativo. 14. ed. atual. São Paulo: Malheiros, 2006.

Niebuhr, Joel de Menezes. GUIMARÃES, Edgar. Registro de preços - Aspectos práticos e jurídicos. Belo Horizonte: Fórum, 2008.

NieBuhr, Joel de Menezes. Licitação pública e contrato administrativo. 2. ed. rev. e ampl. Belo Horizonte: Fórum, 2012.

Olıvo, Luis Carlos Cancellier de. Pregão eletrônico e presencial. Florianópolis: UFSC, 2012.

SANTANA, Jair Eduardo. Pregão presencial e eletrônico. 3. ed. Belo Horizonte: Fórum, 2009. Planejamento nas licitações e contratações governamentais: estratégia para suprimentos públicos. Curitiba, PR: Editora Negócios Públicos, 2015.

SECCHI, Leonardo. Análise de políticas públicas: diagnóstico de problemas, recomendação de soluções. São Paulo: Cenage Learning, 2016.

TRIBUnal de CONTAS DA União (TCU). Manual do Pregão Eletrônico. Brasília. 2010. Disponível em < https://portal.tcu.gov.br/lumis/portal/file/fileDownload. jsp?fileld=8A8182A24D6E86A4014D71A8CC475F20.>. Acesso em: 02 nov. 2018.

Triviños, Augusto N. S. Introdução à pesquisa em Ciências Sociais: a pesquisa qualitativa em educação. São Paulo: Atlas, 1987.

Vergara, Sylvia Constant. Projetos e relatórios de pesquisa em Administração. 12. ed. São Paulo: Atlas, 2010. 


\section{Meryellem Yokoyama Neves}

(i) https://orcid.org/0000-0002-7977-0651

Mestra em Administração Universitária pela Universidade Federal de Santa Catarina, especialização em Administração, Gestão Pública e Políticas Sociais pela Faculdade Dom Bosco e graduação em Ciências Contábeis pela Universidade Federal de Santa Catarina. Atualmente é servidora da Universidade Federal de Santa Catarina, na função de pregoeira no Departamento de Licitações. Tem experiência na área Fiscal e em Compras Públicas.

$\bigotimes$ meryellem@yahoo.com.br

\section{Rafael Pereira Ocampo Moré}

(iD) https://orcid.org/0000-0001-8841-2920

Bacharel e Mestre em Administração pela UFSC (2008 e 2012) e Doutor em Administração do Programa de Pós-Graduação em Administração da Universidade do Vale do Itajaí (UNIVALI) 2016, com bolsa CAPES. Doutorado sanduíche (2013-2014) na Universidade Politécnica de Valência - UPV, Valência/Espanha (bolsa Capes) nos temas Governança, Conhecimento e Inovação em Habitats de Inovação. Atualmente professor do Programa de Pós-graduação em Administração Universitária - PPGAU e coordenador do Programa Universidade Aberta do Brasil - UFSC/UAB.

$\bigotimes$ rafamore@gmail.com 